\title{
The Changes of Disclosure in Compliance with the New Regulations in Jordan
}

\author{
Bilal Omar ${ }^{1}$ \\ ${ }^{1}$ Accounting Department, Administrative and Financial Sciences School, The University of Petra, Amman, Jordan \\ Correspondence: Bilal Omar, Accounting Department, Administrative and Financial Sciences School, The \\ University of Petra, Amman, P.O. Box 961343, Jordan. Tel: 962-679-628-7043. E-mail: drbilalfayz@ yahoo.com
}

Received: December 6, 2014

Accepted: December 25, 2014

Online Published: January 25, 2015

doi:10.5539/ibr.v8n2p155

URL: http://dx.doi.org/10.5539/ibr.v8n2p155

\begin{abstract}
The study investigates the differences in the disclosure practices (mandatory and voluntary) for 60 Jordanian companies listed in Amman Stock Exchange (ASE), before the regulations (1996) and after (2003). The evaluation is conducted using the mandatory and voluntary indices. Furthermore, the relationship between mandatory and voluntary disclosure will be tested in order to determine the effect of mandatory disclosure on the level of voluntary disclosure. The study adopted a sequential explanatory triangulation design which incorporated both quantitative and qualitative data collection and analysis. Various statistical techniques (e.g. paired sample t-test and Wilcoxon signed rank test) were employed using a matched pairs sample (60 companies)
\end{abstract} in 1996 and 2003.

The results indicate that there was a significant increase in the level of mandatory disclosure for Jordanian companies in 2003 compared with 1996. However, the level of voluntary disclosure did not differ significantly for Jordanian companies in the periods, 1996 and 2003. In addition, the findings revealed a significant positive association between mandatory and voluntary disclosure for Jordanian companies. Thus, it could be concluded that the new regulations affect positively the level of voluntary disclosure.

Finally, the interview results suggested that extensive regulation may improve the level of disclosure, with the provision that too many regulations could be a burden or source of confusion for companies.

Keywords: interview, Jordan, mandatory and voluntary disclosures, regulations, sequential explanatory triangulation design

\section{Introduction}

Disclosure practices are the means to satisfy the crucial need for such information. "The disclosure of accounting information has a great impact on the behaviour of investors with respect to buying and selling of stocks in the capital and financial market" (Al-Mulhem, 1997, p. 1). The issue of mandatory disclosure (MD) and voluntary disclosure (VD) has become significant in the literature in both developed and developing countries (Robertson et.al, 2012:380). Disclosure is a complex mechanism, which could be interpreted differently (Adina and Ion, 2008:1408). Firms could disclose information to enhance the efficiency of its production, and to comply with regulations and social values (Adina \& Ion, 2008, p. 1408).

Before 1997, disclosure practice in Jordan was voluntary in nature. Suwaidan (1997, p. 2) argued that due to the lack of regulations and the unregulated nature of The Amman Financial Market (AFM), the majority of annual reports information for listed companies was disseminated voluntarily. In addition, Solas (1994, p. 45) reported two major attributes of financial reporting practice in Jordan before 1997:

1) The AFM had no disclosure regulations.

2) Jordanian companies disseminated information to users on a voluntary basis.

However, one could argue that the change in disclosure practice could be ascribed to the changing of regulations. Inchausti (1997, p. 6) pointed out that the changing of regulators and enactments in Spain was one of the main reasons for change in disclosure practices. In addition, Owusu-Ansah (2005, p. 106) in New Zealand found that the compliance with disclosure requirements was higher for the post mandatory action period than the pre mandatory action period. He (2005, p. 108) ascribed this result to the stringent enforcement introduced by the 
regulators. Moreover, Abd-Elsalam (1999) explored the disclosure practices in the Egypt, which has adopted the International Accounting Standards (IASs). She found that disclosure in Egyptian listed companies was greater in 1995 than 1991.

In Jordan, Al-Shiab (2003) examined the compliance with IASs for Jordanian industrial companies over the period 1995-2000. He (2003, p. 280) found that the compliance with IASs was higher for the post mandatory action period (1998-2000) than the pre mandatory action period (1995-1998). Nonetheless, he (2003, p. 280) discovered that there was a drift up (not a jump up as he expected) in the level of disclosure over the period 1995-2000. Furthermore, Al-Akra et al. (2010, p. 170) argued that regulations could be used as an enforcement tool for compliance. They (2010, p. 171) reported that limited studies tested the compliance of MD in developing countries. Hence, a study on the effect of regulations on disclosure in a Middle East country like Jordan, could enhance our understanding about the factors, which influence disclosure practices in these countries (Al-Akra et al., 2010, p. 170).

Furthermore, the interaction between MD and VD should be taken into consideration, when exploring the disclosure behavior for the firm (Omar \& Simon, 2011, p. 167). Einhorn (2005, p. 594) argued that most of the studies has explored the VD, as the only available disclosure tool, and has ignored the MD. However, MD could affect the content of VD and could enhance the firm's disclosure strategies (Einhorn, 2005, p. 594).

Hence, this study is concerned with examining the level of mandatory disclosure for Jordanian companies listed in Amman Financial Market (AFM). The study will attempt to reveal whether Jordanian corporations comply with the regulations and enactments, specifically the new ones (e.g. The Temporary Securities Law No.23, 1997). In addition, the study will test the relationship between MD and VD.

\section{Literature Review}

\subsection{Benefits and Costs of Regulated Disclosure}

Broberg et al. (2010, p. 352) argued that capital markets influence the extent and content of firms' disclosure. However, there is a trade-off between the benefits and costs of increased disclosure. Therefore, regulating disclosure is expected to provide more benefits than costs and companies may comply with mandatory disclosure.

In addition, Raffournier (1995, p. 261) argued that financial disclosure is being more and more regulated under the law and requirements of many developed countries (e.g. United States, United Kingdom, Germany and France); companies are required to disclose a larger set of information due to the various needs of users. On the other hand, regulation is less effective in developing countries and hence there is a lack of stringent enforcement of financial disclosure, which would enhance its level, in such countries (Ali, Ahmed, \& Henry, 2004, p. 183).

The major benefit from mandating disclosure is to protect users from the effect of any information being hidden by managers. Another advantage of mandatory disclosure is that investors rely on regulated information more than any other kind of information (Al-Mulhem, 1997, p. 54). The fairness and reliability of such information encourages companies to comply with requirements. Moreover, El-Gazzar and Fornaro (2012, p. 74) discussed that absence of regulations could increase the tendency for disclosing unfavorable information. Therefore,

"The aim of mandatory disclosure is to satisfy the users' information needs, ensuring the production quality control through the laws and standards' observance" (Adina \& Ion, 2008, p. 1409).

Furthermore, Taplin et al. (2002, p. 175) pointed out that enforcement is an essential mechanism to monitor compliance with accounting rules. Indeed, the high level of non-compliance requires a more effective regulatory system, specifically the imposition of sanctions for non-compliance. However, the presence of such regulations does not guarantee compliance (Tsalavoutas, 2011, p. 390). Indeed, the high degree of non-compliance may lead to more governmental intervention in the accounting regulatory process, specifically with compliance to accounting rules (Taplin et al., 2002, p. 175).

\subsection{The Effect of New Regulations on Financial Disclosure}

Compliance with mandatory disclosure is a more important issue since the release of new regulations. The reason for that is to evaluate whether the new regulations have increased the degree of compliance or not. Walker and Mack (1998, p. 51) argued that the significance of regulation would be assessed by exploring its requirements and whether it led to changes in disclosure practices.

In recent years, a few studies have been conducted in developing countries, which deal with the degree of compliance to mandatory disclosure. In Saudi Arabia, Al-Mulhem (1997) investigated the level of compliance with new statutory requirements. Before 1986, disclosure requirements were limited in the Saudi environment. In 
1986, a General Presentation and Disclosure Standard (GDPS) was prepared to ensure that companies apply a level of disclosure in their annual reports. After testing the annual reports for 40 corporations, he discovered that none of the Saudi companies examined were fully complying with mandatory disclosure (Al-Mulhem, 1997, p. 279). Moreover, he (1997, p. 259) reported that similar findings on non-compliance with all mandatory disclosure items had been obtained in other studies in developing countries (Wallace, Nigeria, 1988; Tai et al., 1990; Abayo, Tanzania, 1992; Ahmed \& Nicholls, Bangladesh, 1994).

Abd-Elsalam (1999, p. 30) argued that before 1991, disclosure by listed firms was low. The situation changed after 1991. A new Capital Market Law was issued in 1992 and the International Accounting Standards (IASs) were mandated in 1993 (Abd-Elsalam, 1999, p. 30). She examined the extent of compliance with the new regulations by using a sample of 20 matched pairs for two periods: before the new regulations (1991), and after the new regulations (1995). The results demonstrated that mandatory disclosure of Egyptian Listed companies had increased significantly in 1995 compared with 1991 (Abd-Elsalam, 1999, p. 253).

Akhtaruddin's study (2005) explored the mandatory disclosure for 94 listed companies in Dhaka Stock Exchange (DSE) in 1999. He (2005, p. 415) found that the extent of mandatory disclosure was poor, with an average $43.53 \%$ (the non-compliance level was $56.47 \%$ ). The minimum score was $17.3 \%$ and the maximum was $72.5 \%$, indicating that many companies in Bangladesh did not meet the regulations requirements. Akhtaruddin (2005, p. 416) recommended that in order to improve the disclosure level, an accounting board should be established in order to enforce the requirements of regulations.

Owusu-Ansah and Yeoh (2005) examined the influence of Financial Reporting Act of 1993 (FRA) on the level of compliance with mandatory disclosure for companies in New Zealand. They $(2005$, p. 95) employed a before and after research design in order to examine the effect of the new regulations. Using different statistical tests, univariate paired t-test revealed that the compliance level for post FRA period (1996-1997) was higher than in the pre FRA period (1992-1993) (Owusu-Ansah \& Yeoh, 2005, p. 106). In addition, multivariate analysis indicated that the enactment of the FRA was the reason for the improvement in the disclosure compliance of New Zealand companies.

In Jordan, Suwaidan's (1997) survey was conducted before the release of the new regulations (Temporary Securities Law No.23, 1997) and the important changes in financial reporting standards. Suwaidan (1997, p. 226) explored the disclosure practices for 102 Jordanian listed companies in Amman Financial Market (AFM). He concluded that the level of voluntary disclosure in Jordanian corporate annual reports was low. He expressed that this could be due a lack of disclosure requirements (Suwaidan, 1997, p. 1). The Companies Act 1989 (the primary source of disclosure regulation in Jordan) requires companies to prepare comparative financial statements audited by external auditors. However, it does not explain the shape and the context of those statements (Suwaidan, 1997, p. 2). Therefore, Suwaidan (1997, p. 2) argued that most of the items in the annual reports were disclosed voluntarily.

Al-Shiab (2003) examined the compliance with IASs of Jordanian industrial companies over the period 1995-2000. He constructed a checklist of 273 items containing questions for each IAS. In order to assess the impact of IASs, Al-Shiab (2003, p. 216) selected two periods: the pre mandatory action period (1995-1998) and the post mandatory action period (1998-2000). The findings of this study showed that the compliance with IASs was higher for the post mandatory action period (1998-2000) than the pre-mandatory action period (1995-1998). Nonetheless, Al-Shiab (2003, p. 280) discovered that there was a drift up (not a jump up as he expected) in the level of disclosure over the total period 1995-2000. In addition, the overall disclosure for both periods (pre and post) was low because the regulatory system in Jordan was less effective.

Following from the preceding debate, this research aims to explore the level of compliance with mandatory disclosure due to those new regulations. It was found in some studies that the level of mandatory disclosure has increased since the new regulations were introduced (Ahmed \& Nicholls, Bangladesh, 1994; Al-Mulhem, Saudi Arabia, 1997; Abd-Elsalam, Egypt, 1999; Al-Shiab, Jordan, 2003).

Ahmed and Nicholls (1994) and Al-Mulhem (1997) examined compliance with new requirements by testing annual reports for companies after introduction of the new regulations. They did not compare those annual reports with others before the implementation of the new regulations. The reason for that may be the proposition that the issue of obligatory standards aims to increase the level of disclosure. "It is assumed that a high level of compliance with mandatory regulations will exist among corporations because of these reforms" (Al-Mulhem, 1997, p. 182).

In order to present a comprehensive picture about the extent of mandatory disclosure, In Egypt, Abd-Elsalam (1999) employed two samples for two periods. She compared the degree of compliance for both samples for two 
different periods: before the new regulations (1991) and after the new regulations (1995) (Abd-Elsalam, 1999, p. 149). In addition, Al-Shiab (2003) examined two periods for two samples: before the enactment of IASs (1995-1998) and after (1998-2000).

This study adopts the second approach (Abd-Elsalam's and Al-Shiab's approach) to assess the degree of compliance with mandatory disclosure. The new enactment in 1997 (Temporary Securities Law, No.23) and the developments of Jordanian Capital Market provide the underpinning for such research. Two periods will be examined: before the new regulations (before 1997) and after.

\subsection{The Association and Interaction between $M D$ and VD}

The relationship between MD and VD has been investigated in previous studies (i.e. Dye, 1985; Dye, 1986; Naser \& Nuseibeh, 2003; Al-Razeen \& Karbhari, 2004; Einhorn, 2005; Broberg et al., 2010; Robertson et al., 2012). However, "there is no clear association between these two concepts" (Popova et al., 2013).

Dye (1985, p. 546; 1986, p. 353) argued in modeling the effect of MD requirements on VD. This effect depends whether MD and VD are substitutes or complements. If both of them are substitutes, the increase of MD requirements will decrease the VD. Whereas, if both of them are complements, the increase of MD requirements will increase the VD.

Naser and Nuseibeh (2003, p. 46) tested the relationship among three types of disclosure: MD, VD related to MD (detailed disclosure of MD), and VD. They (2003, p. 46) discovered a positive relationship between MD and VD related to MD. This result could support Dye's $(1985,1986)$ perspective that MD and VD are complements. On the other hand, Naser and Nuseibeh (2003, p. 60) found no relationship between VD and the other two types of disclosure. They explain such a result by sources of information, which form each type of disclosure. MD and VD related to MD disclosures are taken from financial statements and notes to the accounts, while VD disclosures are derived from the directors' report.

Moreover, a study by Al-Razeen and Karbhari (2004, p. 358) revealed similar results to Naser and Nuseibeh's (2003) study. Indeed, they found that there is no clear pattern of association between MD and VD. Thus, it could be noted that there is a low-coordination between board of directors and the management in preparing the annual reports. The study $(2004$, p. 358) concluded that most of VD items were found in the directors' report, whereas, the other types of disclosures (MD and VD related to MD) items were found in the financial statements and the notes.

Einhorn (2005, p. 612) argued that most of existing studies do not take into consideration the interaction between MD and VD. He (2005, p. 594) analyzed how MD requirements affect discretionary disclosure strategies of the firm. He found that the likelihood of providing VD by firms is independent on the MD contents. In addition, there is a nonmonotic relationship between the likelihood of VD and the information quality of MD. Moreover, Einhorn (2005, p. 613) concluded that there is a negative relationship between VD and the discretion of MD, and there is a positive relationship between VD and the scope of disclosure requirements.

Broberg et.al (2010, p. 358) tested the relationship between the increased MD and VD content. The results revealed that there is a positive association between increased MD and VD content. In particular, after introducing IAS, the companies disclosed more voluntary information about share related information (Broberg et al., 2010, p. 363).

A recent study by Robertson et.al (2012, p. 382), explored the association between VD related and VD unrelated information on MD. They (2012, p. 386) found that VD related information is positively associated with MD, while VD unrelated information is negatively associated. The findings of this study imply patterns for managers, which enable them to develop disclosure policies (Robertson et al., 2012, p. 386).

\section{Jordanian Regulatory Environment}

The Securities Exchange Law (SEL) requires companies, whose shares are traded in the stock exchange, to disclose adequate information to the public in order to protect investors and enable them to take the appropriate decisions. The first law in Jordan concerning the financial market was in 1976. AFM Law No.31 for the year 1976 was the basis of establishment of the AFM in Jordan, which started operation in 1978. The AFM Law of 1976 was amended by the AFM Law No 11990.

The enactment of the Temporary Securities Law No.23 for the year 1997 was a landmark. Indeed, it was a qualitative leap and a turning point for the Jordanian capital market. The major purpose of this enactment is to restructure and regulate the Jordanian capital market and to achieve transparency in the market in line with international standards (Note 1). There are two main features of this law: 
1- The establishment of Amman Stock Exchange (ASE) in 1999, as a replacement for AFM. This restructuring leads to the separation of supervisory and legislative role from the executive role. In addition, three independent entities were established, according to this law, instead of AFM: ASE, the Securities Deposity Centre (SDC), which plays the executive role, and Jordan Securities Commission (JSC) which plays the supervisory and legislative role.

2- Directives of Disclosure and Auditing and Accounting Standards (DDAAS).

The major feature of DDAAS is its significant role in determining IASs as the basis of preparation of the financial statements for Jordanian public shareholding companies. Indeed, IASs were applied in Jordan from 1998 under the Securities Law No 23 for 1997.

It is reasonable to think that the Securities Law no.23 for 1997 was the first regulation which specified the disclosure requirements in the annual reports. In addition, the Law was the major vehicle of imposing IASs for Jordanian shareholding companies.

Therefore, this Law is considered to be the first vehicle of mandatory disclosure in Jordan, since disclosure requirements under DDAAS and IASs were mandated by this Law. Before 1997, disclosure practices in Jordan were voluntary in nature, due to the lack of regulations and the unregulated nature of the AFM (Suwaidan, 1997, p. 2).

\subsection{The Influence of Regulatory Bodies on Disclosure in Jordan}

\subsubsection{Amman Financial Market (AFM)}

The AFM is considered to be a public financial institution with legal, administrative and financial independences from the state. The operations of AFM started on January 1, 1978. The AFM started with 51 listed companies, with a market capitalisation of JD 286 million and trading volume of JD 9.7 million in 1978. In 2012, the number of companies reached 243, the market capitalisation reached JD 19.1 billion with a trading volume of JD 2 billion (Note 2).

One of the fundamental changes in Jordanian capital markets was the restructuring effort, the purpose of which was to separate the supervisory and legislative role from the executive role. Thus, three new institutions were established to replace AFM, as is shown next.

\subsubsection{Amman Stock Exchange (ASE)}

The ASE was established on March 11, 1999. The listed companies in the ASE used to be classified into four sectors: banking, insurance, services and industrial (Al-Shiab, 2003, p. 63).

Significant development in ASE started in 2003 (the year of data collected in this study), since the major improvements in the regulatory environment occurred in that year, specifically after the issuance of the Securities Laws 1997 and 2002. "The JSC has enhanced transparency by requiring companies to disclose the information and the significant matters in order to protect the investors" (Al-Khasib, 2004) (Note 3).

\subsubsection{Jordan Securities Commission (JSC)}

JSC has a legal personality with financial and administrative autonomy, and is linked directly to the Prime Minister. In addition, various regulations and instructions have been issued under the supervision of JSC. For example, it imposes the IASs and the international auditing standards, which auditors shall follow. The supervision role of JSC aims to protect investors and to ensure the compliance with laws and regulations.

\subsubsection{The Securities Depository Centre (SDC)}

The SDC is a non-profit legal entity with financial and administrative autonomy, and managed by the private sector. The SDC is considered to be one of the most important institutions in AFM, as it holds the ownership register of all issued shares.

\section{Research Methodology}

\subsection{Triangulation (Mixed Methodology)}

Morse (1991, p. 120) defined methodological triangulation as "the use of at least two methods, usually qualitative and quantitative, to address the same research problem".

Triangulation can be used to overcome the possible bias and deficiencies of a single-method approach (Collis \& Hussey, 2003, p. 78).

In this research, the quantitative method is the primary method of research, since it achieves the main objective of the study. Qualitative methods (interviews) are employed in order to provide a more comprehensive 
perspective and understanding about the research problem. "Even if you have adopted a positivistic approach, you may have collected qualitative data in order to provide richness and give insight to the numerical data" (Collis \& Hussey, 2003, p. 254).

Qualitative data were collected by means of semi-structured interviews. The resulting data was analysed using general analytical procedures (The purpose of the interviews was to explain and enhance the understanding of the findings of the quantitative data.) Mixing quantitative and qualitative methods (methodological triangulation) provides a fuller and more comprehensive picture about the study (Neuman, 2006, p. 150). This type of triangulation will be used in this study.

\subsection{Sample Selection}

Matched annual reports were obtained for 60 companies for the periods before (1996) and after (2003) the issue of The Securities Law No. 23, 1997, when IASs were introduced in Jordan (Note 4). The reason for choosing the year 1996 is because it is the year prior to issue of the Law, while 2003 was chosen since it allows sufficient time for the new regulations to become established and understood by the corporate sector. The industrial and services sectors were chosen in this study since banks and insurance companies are subject to specific and different disclosure requirements (e.g. IAS No.30). The selection of the sample was undertaken in a two-step process:

1- Personal visits were made to the ASE in order to obtain the annual reports for both periods (1996 and 2003). Some companies had merged with others, had been de-listed from the ASE or gone out of business, and thus could not be included in this study. After several visits to the ASE library and to the companies themselves (Note 5) 65 annual reports were obtained for industrial and services companies listed in ASE in the year 1996, and a matching set of their annual reports for the year 2003.

2- From the 65 annual reports, five companies could not be included in the sample. Four of them contained incomplete information, particularly the chairman's report (it contained only the financial statements information); and the financial year for one company (Al-Zay Company) was not at the end of the calendar year. (Note 6).

Thus, 60 companies were the final sample and the annual reports were collected for both periods: 1996 and 2003. This sample contained 38 industrial companies and 22 services companies. The descriptive statistics related to this sample are displayed in Table 1:

Table 1. Descriptive statistics of the matched pairs sample

\begin{tabular}{ccccccccc}
\hline & \multicolumn{9}{c}{1996} & \multicolumn{3}{c}{2003} \\
\cline { 2 - 8 } Item & Mean & Maximum & Minimum & Std. deviation & Mean & Maximum & Minimum & Std. deviation \\
\hline Total assets & $30,374,104$ & $390,773,547$ & 314,506 & $79,372,966$ & $34,427,856$ & $342,994,000$ & $1,239,430$ & $70,335,021$ \\
Sales & $20,946,340$ & $493,458,976$ & 28,649 & $73,078,824$ & $29,547,594$ & $793,267,740$ & 24,919 & $107,981,409$ \\
Capital stock & $7,954,921$ & $79,695,000$ & 174,500 & $11,944,169$ & $11,566,584$ & $83,318,000$ & 500,000 & $16,178,921$ \\
Net income & $1,359,996$ & $34,189,517$ & $-4,547,787$ & $4,953,497$ & 215,800 & $8,649,50$ & $-58,000,000$ & $7,930,533$ \\
\hline
\end{tabular}

\subsection{Construction of Mandatory Disclosure Index}

The disclosure index is an appropriate tool to explore the nature (quality) and the extent (quantity) of disclosure. Marston and Shrives (1991, p. 195) stated that a disclosure index has various functions and purposes. It could be used to determine the extent of disclosure among different companies. In addition, it could be used to show the compliance with regulations (mandatory and voluntary) or it can be employed to measure the level of voluntary disclosure.

For the purpose of this study, a mandatory disclosure index was developed to measure compliance with the new regulations. It consists of 278 items of information. The index was constructed based on the following:

1- The items required by regulations and enactments in Jordan, specifically those mentioned in The Directives of Disclosure and Auditing and Accounting Standards No (1) for 1998 which were published in the Official Gazette on 16th April 1998, and came into effect on 1st September 1998. In addition, the Company Act, 1989; the Audit Law, 1985; the Tax Law, 1985; the Temporary Securities Law No.23, 1997 and Stock Exchange requirements and International Accounting Standards (IASs). 
2- A review of disclosure literature to identify items relevant to this study (i.e. Buzby, 1975; Firth, 1979; Chow \& Boren, 1987; Wallace, 1988; Cooke, 1989; Raffournier, 1995; Hossain, Perera, \& Rahman 1995; Abd-Elsalam, 1999; Naser \& Nuseibeh, 2003; Khanna, Palepu, \& Srinvasan, 2004;), with a focus on the studies which investigated financial disclosure in Jordan ( Al-Issa, 1988; Suwaidan, 1997; Al-Shiab, 2003).

3- Items included in the annual reports issued by Jordanian companies listed in the Amman Financial Market (AFM) which contain, besides the financial statements, various quantitative and qualitative information.

There are two major vehicles for mandatory disclosure in Jordan: The Securities Law No. 23 for the year 1997, and IASs. In addition, Al-Shiab's index (2003) and Abd-Elsalam's index (1999), which covered IASs, were used to support the mandatory index. Other regulations in Jordan which include compulsory disclosure were used.

It should be noted, regarding construction of the disclosure index, that a pilot test of a sample of the annual reports for the year 2003 for Jordanian companies was conducted to ensure the relevance of his index.

Another reason for the importance of the pilot survey is related to the mandatory items, specifically IASs items. Many IASs relate to accounting practices which are uncommon among Jordanian companies, due to the nature of their activities and their accounting systems. In addition, some regulations are inconsistent with these standards. For example, IAS 26: Accounting and Reporting by Retirement benefit plans is not applied by Jordanian companies since accountants are not familiar with this standard and there is a lack of regulations about this issue.

The dichotomous approach was used for scoring the index: 1 point was given for the item if disclosed and 0 point is given for the item if not disclosed. The unweighted approach was employed; since the focus of this study is on the different types of users and the number of items is large (278 items). The main justification for using this approach is to measure the extent of mandatory disclosure and the quantity of information disclosed, instead of measuring the importance of such disclosure. In addition, Hossain and Hammami (2009:259) discussed that using weighted and unweighted scores would make little or no difference on the results. This approach has been employed in several prior studies (i.e. Cooke, 1989; Ahmed \& Nicholls, 1994; Raffournier, 1995; Inchausti, 1997; Haniffa \& Cooke, 2002; Al-Shiab, 2003; Hossain \& Hammami, 2009; Al-Akra et al., 2010; Omar \& Simon, 2011; Al-Akra \& Hutchinson, 2013; Popova et al., 2013).

The mandatory disclosure (MD) score for a company was calculated as follows:

$$
M D=\sum_{i=1}^{278} j_{i} / m_{j}
$$

Where

$$
\begin{gathered}
\mathrm{J}=\left\{\begin{array}{l}
1 \text { if the item is disclosed } \\
0 \text { if the item is not disclosed }
\end{array}\right. \\
\mathrm{m}_{\mathrm{j}}=\text { number of items applicable to a company }
\end{gathered}
$$

In addition, the voluntary disclosure (VD) score for a company was calculated as follows:

$$
V D=\sum_{i=1}^{53} j_{i} / m_{j}
$$

Where

$$
\begin{aligned}
& \mathrm{J}=\left\{\begin{array}{l}
1 \text { if the item is disclosed } \\
0 \text { if the item is not disclosed }
\end{array}\right. \\
& \mathrm{m}_{\mathrm{j}}=\text { number of items applicable to a company }
\end{aligned}
$$

Street and Bryant (2000, p. 315) argued that a review of the entire annual reports could reduce the possibility that companies would be penalised for not disclosing non applicable items.

\section{Results}

\subsection{Descriptive Statistics}

Table 2 shows the mean of mandatory and voluntary disclosure for industry and services companies for both 
periods: 1996 and 2003.

Table 2. The mean of Mandatory and Voluntary disclosure level for services and industries companies for both periods: 1996 and 2003

\begin{tabular}{lcccccccc}
\hline & \multicolumn{2}{c}{ Companies } & \multicolumn{3}{c}{ Mandatory disclosure mean } & \multicolumn{3}{c}{ Voluntary disclosure mean } \\
\cline { 2 - 9 } Sector & No & $\%$ & $1996(\%)$ & $2003(\%)$ & Change $(\%)$ & $1996(\%)$ & $2003(\%)$ & Change $(\%)$ \\
\hline Services & 22 & 36.66 & 64.53 & 81.16 & +16.63 & 32.10 & 35.47 & +3.37 \\
Industry & 38 & 63.33 & 68.19 & 85.35 & +17.16 & 33.51 & 36.62 & +3.11 \\
\hline
\end{tabular}

The table above shows that the mean of mandatory and voluntary disclosure was greater for industrial companies than services companies for periods, 1996 and 2003. As regards the mean of mandatory disclosure level, the mean increased for both sectors from 1996 to 2003 (16.63\% and 17.16\% respectively). Voluntary disclosure level increase for both sectors from 1996 to 2003 (3.37\% and 3.11\% respectively). While the mean of mandatory disclosure level change was greater for industrial companies than services ones, the mean of voluntary disclosure level change was greater for services companies than industrial ones.

\subsection{The Change in Disclosure Practices for Periods, 1996 and 2003}

Table 3 summarizes the descriptive statistics of the two indices: mandatory disclosure (MD) and voluntary disclosure (VD) for the 60 companies in the periods, 1996 and 2003.

Table 3. Descriptive statistics to the two indices: Mandatory disclosure and Voluntary disclosure for periods, 1996 and 2003

\begin{tabular}{ccccccc}
\hline & \multicolumn{3}{c}{ Mandatory disclosure } & \multicolumn{3}{c}{ Voluntary disclosure } \\
\cline { 2 - 6 } & 1996 & 2003 & Change $( \pm \%)$ & 1996 & 2003 & Change $( \pm \%)$ \\
\hline Mean (\%) & 66.85 & 83.16 & +16.31 & 32.99 & 36.20 & +3.21 \\
Maximum (\%) & 79.85 & 93.75 & +13.90 & 65.38 & 70.59 & +5.21 \\
Minimum (\%) & 52.73 & 63.87 & +11.14 & 14.00 & 10.00 & -4.00 \\
Std. deviation (\%) & 5.68 & 5.55 & -0.13 & 9.59 & 12.90 & +3.31 \\
\hline
\end{tabular}

As seen from the table above, there was an increase in the mean of all two indices. The largest increase was for the mandatory disclosure index $(+16.31)$, while the voluntary disclosure index mean increased slightly $(+3.21 \%)$ from $32.99 \%$ in 1996 to $36.20 \%$ in 2003 . The increase in the maximum score for the two indices, was higher for the mandatory index $(+13.90)$, than the voluntary index $(+5.21 \%)$.

Similarly, the minimum score increased for the mandatory index (+11.14) more than voluntary index which decreased from $14 \%$ to $10 \%$.

These results illustrate that the level of disclosure has increased in 2003 compared with 1996. The new regulations (i.e. Securities Law No.23 for the year 1997) could be the reason for this increase, particularly as the case of greatest increase was mandatory disclosure. Therefore, further analysis of the extent of mandatory disclosure was conducted as shown in the next table.

Table 4. Extent of mandatory disclosure according to DDAAS requirements, IASs requirements and DDAAS+IASs requirements

\begin{tabular}{lccccccccc}
\hline & \multicolumn{3}{c}{ DDAAS } & \multicolumn{3}{c}{ IASs } & \multicolumn{3}{c}{ DDAAS+IASs } \\
\cline { 2 - 10 } & 1996 & 2003 & Change $( \pm \%)$ & 1996 & 2003 & Change $( \pm \%)$ & 1996 & 2003 & Change $( \pm \%)$ \\
\hline \multicolumn{1}{c}{ Mean (\%) } & 59.91 & 85.47 & +25.56 & 69.24 & 82.56 & +13.32 & 60.07 & 91.56 & +31.49 \\
Maximum (\%) & 82.61 & 100.00 & +17.39 & 79.00 & 92.63 & +13.63 & 81.82 & +100.00 & +18.81 \\
Minimum (\%) & 31.82 & 29.17 & -2.65 & 53.75 & 68.35 & +14.60 & 44.44 & 50.00 & +5.56 \\
Std. deviation (\%) & 9.81 & 12.80 & +2.99 & 6.03 & 5.53 & -0.50 & 8.06 & 12.64 & +4.58 \\
\hline
\end{tabular}


The table shows that the level of compliance with mandatory disclosure regulations (DDAAS, IASs and DDAAS+IASs) increased significantly in 2003 compared to 1996. The greatest increase in the mean was related to DDAAS+IASs regulations $(+31.49 \%)$.

In addition, the mean of the DDAAS regulation increased by $25.56 \%$, and that of IASs increased by $13.32 \%$. Moreover, in 2003 (the post-regulation period), there was full compliance with DDAAS and DDAAS+IASs regulations among Jordanian companies (see Table 3). However, no company (of the 60 sampled) was found to be fully-compliant with IASs regulation (the maximum was 92.63\%). Nevertheless, this is an improvement over 1996, when no company fully complied with the regulations, and the maximum scores were $82.61 \%, 79 \%$ and $81.82 \%$ for DDAAS, IASs and DDAAS+IASs respectively.

The evidence seems to indicate that the level of disclosure has been improved for Jordanian companies, since the enactment of the new regulations (i.e. Sec Law No.23 for the year 1997). DDAAS are mentioned clearly in the annual reports for the year 2003 according to Securities Law No.23 for the year 1997 (Note 7). Meanwhile these requirements were voluntarily disclosed by the companies in 1996. Thus, the level of DDAAS disclosure in 2003 was more than the level in 1996 (see Table 4). In addition, IASs were applied in Jordan from 1998 under the Securities Law No.23 for the year 1997 (Note 8), although, Jordanian companies were voluntarily disclosing IASs in their annual reports in 1996 (the mean of IASs in 1996 was 69\%). Nonetheless, the response to the mandating of IASs was positive, leading to an increased level of compliance for IASs to $83 \%$ in 2003. Moreover, the items which were required by more than one regulation (DDAAS+IASs) had the highest degree of compliance by Jordanian companies in 2003. The average of DDAAS+IASs regulation disclosure was $91 \%$. Hence, it could be inferred that more regulations (e.g. stock exchange and IASs regulations) could increase the level of compliance, since the control over non-compliance will be more effective.

Comparing with previous studies, Owusu-Ansah and Yeoh (2005) discovered that the compliance level for post Financial Reporting Act of 1993 (FRA) period was higher than those in the pre-FRA period in New Zealand. In Egypt, Abd-Elsalam (1999) found that the level of disclosure for Egyptian listed companies increased significantly in 1995 (post-period) compared to 1991 (pre-period).

In Jordan, Al-Shiab (2003) found that the compliance with IASs was higher for the post mandatory action period (1998-2000) than the pre mandatory action period (1995-1998). Nonetheless, he (2003, p. 280) concluded that there was a drift up (not a jump up as he expected) in the level of disclosure over the period 1995-2000. In addition, he found that the disclosure level was quite low for both periods because the regulation system in Jordan was not efficient enough to impose the requirements.

In this study, the response to mandatory requirements was greater than reported by other studies in Jordan, since the level of compliance with each mandatory regulation was high, as seen in Table 3 . Therefore, it is reasonable to think that the regulations in Jordan play a vital role in increasing the level of disclosure.

\subsection{Testing the Differences in the Disclosure Indices for both Periods, 1996 and 2003}

Table 5. Paired samples statistics for MD 1996 and MD 2003

\begin{tabular}{cccccc}
\hline & & No & Mean $(\%)$ & Std. deviation $(\%)$ & Std. error mean (\%) \\
\hline \multirow{2}{*}{ Pair 1 } & MD 1996 & 60 & 66.85 & 5.08 & 0.73 \\
& MD 2003 & 60 & 83.81 & 5.55 & 0.71 \\
\hline
\end{tabular}

Table 6. Paired sample test for MD 1996 and MD 2003

\begin{tabular}{lcccccc}
\hline & Paired difference mean (\%) & Std. deviation (\%) & $\mathrm{t}$ & $\mathrm{df}$ & Sig (2-tailed) \\
\hline Pair 1 & MD 1996 & & & & & \\
& MD 2003 & -16.96 & 5.31 & -24.702 & 59 & 0.000 \\
\hline
\end{tabular}

Table 5 reveals that there was a significant difference in the extent of mandatory disclosure for Jordanian companies for the two periods, 1996 and 2003, since the significance value is less than $5 \%(\mathrm{p}=0.000)$. In addition, Table 5 illustrates that the mean score for MD in 2003 was higher than the mean score for MD in 1996 (83.85>66.85). Therefore, the evidence seems to indicate that the mandatory disclosure level had increased in 2003 compared to 1996. 
Furthermore, the previous results are supported by Wilcoxon signed rank as shown in the following tables:

Table 7. Ranks for MD 1996 and MD 2003

\begin{tabular}{ccccc}
\hline & & N & Mean rank & Sum of ranks \\
\hline MD 1996-MD 2003 & Negative ranks & 0 & 30.50 & 0.00 \\
& Positive ranks & 60 & & 1830.00 \\
& Ties & 0 & & \\
\hline & Total & 60 & & \\
\hline
\end{tabular}

Table 8. Test statistics for MD 1996 and MD 2003

\begin{tabular}{cc}
\hline & AD 1996- AD 2003 \\
\hline$Z$ & -6.736 \\
Asymp.Sig (2-tailed) & 0.000 \\
\hline
\end{tabular}

As shown in Table 7, all the companies (60) had positive scores, which indicates that the level of disclosure for the whole sample in 2003 was higher than the level in 1996. The negative $Z$ score in Table 8 (-6.736) indicates that there was a significant increase in the level of mandatory disclosure in 2003 compared to 1996 ( $p=0.000)$. Thus, the results in both tests (parametric and non-parametric) are similar.

The mandatory disclosure index (MD) comprises three partial indices according to the regulations: DDAAS index, IASs index and DDAAS+IASs index. The change in the level of each index was examined for the periods, 1996 and 2003, in order to determine the impact of each regulation on the level of mandatory disclosure. The following analyses will explain the outcomes.

Table 9. Ranks for DDAAS, IASs and DDAAS+IASs indices in periods, 1996 and 2003

\begin{tabular}{llccc}
\hline & & $\mathrm{N}$ & Mean rank & Sum of ranks \\
\hline DDAAS 1996-DDAAS 2003 & Negative ranks & 4 & 17.50 & 46.00 \\
& Positive ranks & 56 & 31.86 & 1784.00 \\
& Ties & 0 & & \\
& Total & 60 & & 0.00 \\
& Negative ranks & 0 & 0.00 & 1830.00 \\
& Positive ranks & 60 & 30.50 & \\
& Ties & 0 & & 4.00 \\
& Total & 60 & & 1826.00 \\
& Negative ranks & 1 & 4.00 & 30.59 \\
\end{tabular}

Table 10. Test of statistics for DDAAS, IASS and DDAAS+IASs indices in 1996 and 2003

\begin{tabular}{cccc}
\hline & DDAAS 1996-DDAAS 2003 & IASs 1996-IASs 2003 & DDAAS+IASs 1996-DDAAS+IASs 2003 \\
\hline $\mathrm{Z}$ & -6.736 & -6.398 & -6.712 \\
Asymp.Sig (2-tailed) & 0.000 & 0.000 & 0.000 \\
\hline
\end{tabular}

Table 9 displays the positive and negative rank scores for each index. Positive ranks reveal that the score for each regulation index (DDAAS, IASs and DDAAS+IASs) in 2003 is higher than in 1996, while negative rank scores mean that scores were higher in 1996 than 2003. Therefore, for the DDAAS index, 56 companies (93\%) disclosed more DDAAS information in 2003 than in 1996. In addition, all the companies (60) disclosed more 
IASs information in 2003 than in 1996. Just one company disclosed more DDAAS+IASs information in 1996 than in 2003, while the other companies (59) disclosed more of such information in 2003 than in 1996.

Furthermore, $\mathrm{Z}$ scores were negative for the three indices as shown in Table 10 (-6.736, -6.398, -6.712 for DDAAS, IASs and DDAAS+IASs respectively), with a significance value less than $5 \%$ for all three indices (p $=0.000$ for each index). Therefore, it can be concluded that there was a significant increase in the level of mandatory disclosure under each regulation (DDAAS, IASs and DDAAS+IASs) in 2003 compared to 1996. In other words, Jordanian companies seem to comply with regulations, specifically the new ones (i.e. Temporary Securities Law No.23 for the year 1997), in their annual reports.

In summary, the new regulations in Jordan have played a significant role in improving the level of mandatory disclosure in the annual reports for Jordanian companies. This is consistent with Tower, Hancock and Taplin's (1999:295) argument that accounting standards can help the preparation of financial statements by mandating a certain format of presentation, requiring explicing measurement techniques, ensuring an increasing in the disclosure level and requiring that additional information is disclosed.

5.3.3 Testing the Differences in the Voluntary Index (VD) in 1996 and 2003

Table 11. Ranks for VD 1996 and VD 2003

\begin{tabular}{lllcc}
\hline & & N & Mean rank & Sum of ranks \\
\hline VD 1996-VD 2003 & Negative ranks & 20 & 28.57 & 1057.00 \\
& Positive ranks & 37 & 29.80 & 596.00 \\
& Ties & 3 & & \\
\hline
\end{tabular}

Table 12. Test statistics for VD 1996 and VD 2003

\begin{tabular}{cc}
\hline & VD 1996- VD 2003 \\
\hline $\mathrm{Z}$ & -1.831 \\
Asymp.Sig (2-tailed) & 0.067 \\
\hline
\end{tabular}

The first table reveals that the number of companies which disclosed more voluntary information in 2003 than in 1996 was 37 (positive ranks). Meanwhile, the number of companies which disclosed more voluntary information in 1996 than in 2003 was 20 companies (negative ranks). Three companies disclosed the same level of voluntary information in periods, 1996 and 2003.

The second table shows that there is no statistically significant difference in the level of VD for the periods, 1996 and 2003, since the significance value is more than $5 \%(\mathrm{p}=0.067)$. Hence, the level of voluntary disclosure for the sample of 60 companies did not differ significantly in 2003 compared to 1996.

As noticed in Table 3, the mean voluntary disclosure level had increased slightly from 33\% in 1996 to 36\% in 2003 for the 60 Jordanian companies. Comparing with previous studies in Jordan, the level of voluntary disclosure was slightly lower than the level of voluntary disclosure in Al-Issa (1988) and Suwaidan (1997) (44\% and 39\% respectively). Therefore, although the level of mandatory disclosure has increased significantly, there are incentives for voluntary disclosure in Jordan. The effect of mandatory disclosure on voluntary disclosure depends on whether mandatory and voluntary disclosures are substitutes or complements. The next discussion will highlight the effect of mandatory disclosure on voluntary disclosure.

\subsection{Testing the Relationship between Mandatory Disclosure and Voluntary Disclosure}

Table 13. Kendall's tau and Spearman's rank correlation results for the relationship between MD 2003 and VD 2003

\begin{tabular}{cccc}
\hline Test & Correlation Coefficient & Sig. (2-tailed) & No. of companies \\
\hline Kendall's tau & 0.338 & 0.000 & 60 \\
Spearman's rank correlation (rho) & 0.461 & 0.000 & 60 \\
\hline
\end{tabular}


The results of both tests reveal a high significant positive relationship between mandatory and voluntary disclosure for the year 2003 (the significance value is less than 0.01). It may be that mandatory disclosure had a positive influence on the level of voluntary disclosure for Jordanian companies. In other words, the increase in the level of mandatory disclosure encouraged an increase in voluntary disclosure.

This result supports the perspective of Naser and Nuseibeh (2003, p. 57), who found a positive and significant association between mandatory and voluntary disclosure. In addition, this result agrees with Dye's (1985:548) argument that mandatory disclosure complements voluntary disclosure.

Moreover, the previous studies in Jordan related to the level of voluntary disclosure were conducted before the new regulations (i.e. Securities Law No.23 for the year 1997). Therefore, their type of disclosure was voluntary by nature. It should be noted that many of the voluntary items that were investigated in previous studies have become mandatory through the new regulations in 1998.

\subsection{Interview Results}

The researcher conducted five interviews with two regulators, two auditors and one financial analyst. The interview questions were designed in accordance with the results of the quantitative data analysis. The purpose of these questions was to enhance our understanding concerning the findings of the quantitative analysis, since the approach applied in this research was a sequential approach in accordance with general analytical procedures, as explained in Section 4.1 in the research methodology. The generalizations which could be concluded from the interview data are summarized as follows:

\subsubsection{Mandatory Disclosure (MD)}

\section{A- MD Level}

The level of MD (82\%) is good, but the respondents expected a higher level (90\% or 95\%). The penalties are the main factor contributing to this level, although they did not exist in 2003. Thus, the level of MD could reach 95\% nowadays, since penalties are imposed on companies.

\section{B- DDAAS, IASs and DDAAS+IASs}

\section{- Compliance}

The compliance with DDAAS requirements and with IASs requirements is similar because the JSC ensures that the compliance should be for all requirements. Compliance with IASs came before compliance with DDAAS, since IASs was applied in Jordan in 1984 by the Companies Act.

\section{- IASs}

Auditors indicated that the compliance with IASs is restricted to the Big Four audit companies for the following reasons:

A- It is required by many regulators, such as: the Companies Act, JSC and other regulations.

B- They are controlled by the main audit offices, which ensure that these audit companies apply IASs when preparing the financial statements.

In summary, JSC's role of ensuring that the compliance with both DDAAS and IASS is illustrated in the next figure.

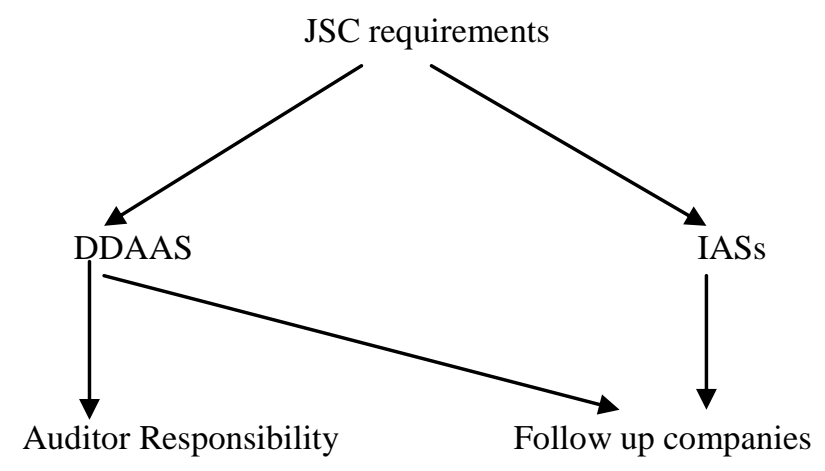

Figure 1. JSC role as regards DDAAS and IASs compliance 


\section{- DDAAS + IASs}

There were different views among interviewees about the effect of many regulations on the compliance level. These views are shown in the next table:

Table 14. Views about the effect of many regulations on the compliance level

\begin{tabular}{cccc}
\hline Interviewee & Group & Positive Effect & No Effect \\
\hline Rababaa & Regulators & $\sqrt{ }$ & - \\
Al-Hadidi & Regulators & $\sqrt{ }$ & - \\
Hammoda & Auditors & - & $\sqrt{ }$ \\
Samara & Auditors & - & $\sqrt{ }$ \\
Abu-Qalbin & Financial Analyst & - & \\
\hline
\end{tabular}

Supporters of a positive effect argued that companies pay more attention to items, which are required by more than one regulator. However, there are limits to their support, since too many regulations could burden and confuse companies.

On the other hand, those who thought there is no effect pointed out that regulations are similar and JSC regulations are drawn from IASs, but in a different frame. In addition, the most appropriate solution to increase compliance is not by imposing more regulations, but by training the regulators themselves to be capable of analysing and imposing such regulations.

\subsubsection{Voluntary Disclosure (VD) and Its Relationship with Mandatory Disclosure}

The extent of voluntary disclosure depends on two major things: the company's management and the company's culture and awareness. Company awareness towards mandatory items is more than for voluntary items, since it is required by regulations. The next table illustrates the different views about the effect of MD (regulations) on VD:

Table 15. Views about the effect of MD on VD

\begin{tabular}{cccc}
\hline Interviewee & Group & Positive Effect & No Effect \\
\hline Rababaa & Regulators & - & $\sqrt{ }$ \\
Al-Hadidi & Regulators & $\sqrt{ }$ & - \\
Hammoda & Auditors & - & $\sqrt{ }$ \\
Samara & Auditors & $\sqrt{ }$ & - \\
Abu-Qalbin & Financial Analyst & - \\
\hline
\end{tabular}

However, there should be a balance between MD and VD. In other words, VD should remain and if the JSC discovers that one or more voluntary item has become essential, it should make it mandatory. An example of VD in Jordan is ratios, which should be reviewed regularly in order to mandate more ratios, which are beneficial for decision making. Finally, companies disclose voluntary information in order to distinguish themselves (signalling theory).

\section{Discussing the Conclusion Results}

This study has investigated the differences in the disclosure practices (aggregate, mandatory and voluntary) for 60 Jordanian annual reports, before the regulations (1996) and after (2003). The results indicate that there was a significant increase in the level of aggregate and mandatory disclosure for Jordanian companies in 2003 compared with 1996. However, the level of voluntary disclosure did not differ significantly for Jordanian companies in the periods, 1996 and 2003. Interviewees ascribed the increase in the disclosure level in Jordan to the development of new regulations, the existence of the JSC, the development of a disclosure culture and awareness, the penalties for non-disclosure and the development of the capital market.

Further analysis of the mandatory disclosure level reveals that Jordanian companies complied with DDAAS+IASs regulations more than each one of them separately. Moreover, the level of compliance with IASs 
was increased from 1996 to 2003. The interview results suggested that extensive regulation may improve the level of disclosure, with the provision that too many regulations could be a burden or source of confusion for companies. Thus, it was suggested that the JSC should review every item carefully before imposing more than one regulation on it. In addition, unifying these regulations into one disclosure law was thought to be worth pursuing, although there are some difficulties.

The relationship between mandatory and voluntary disclosure was examined in order to indicate the impact of the new regulations on the voluntary disclosure level. The findings revealed a significant positive association between mandatory and voluntary disclosure for Jordanian companies. Thus, it could be concluded that the new regulations affect positively the level of voluntary disclosure. This finding supports Dye's (1985) perspective that mandatory disclosure complements voluntary disclosure.

\section{Implications and Recommendations}

The most notable finding of the study is the increase in the level of mandatory disclosure for Jordanian companies. This increase could be ascribed, according to the interview results, to the development of a new regulatory system in Jordan and the existence of the JSC, as the major regulatory body in AFM. This result supports the regulation theory which argues that regulations are one of the significant factors which cause development in disclosure. Moreover, this result implies that the increase in financial disclosure level is a reaction to the changes in the Jordanian economy. Jordan has adopted a private Sector led approach to dominate the economy and the Jordanian Capital Market has been separated into three new institutions: ASE, JSC and SDC. These changes were intended to attract new investments and to establish a well-planned investment environment in Jordan. Therefore, developing a new regulatory system was one of the most important tools to enable Jordan to achieve its economic and investment goals.

Furthermore, the study indicated that the JSC is the most important regulator which affects the level and nature of disclosure in Jordan. In addition, the existence of the JSC is the major reason for improvement in the disclosure level in Jordan, since the enforcement mechanism was introduced when it come into existence.

Another important note is the comparison with previous studies in Jordan revealed that Jordan has started a new era of disclosure under a new regulatory system. Moving from voluntary to mandatory disclosure requires full cooperation among the different regulators in Jordan such as the JSC, ASE, SDC, JACPA, and the Companies Controller (Financial Controller). Unifying all the disclosure requirements of the different laws, in one disclosure law could improve compliance and could help users to improve their decision making effectiveness; however, unification is still difficult to achieve.

Finally, the interaction between mandatory and voluntary disclosure suggests that mandatory and voluntary disclosure are not separate elements in financial reporting. Both should be taken into consideration when exploring the disclosure issue and its related behaviour. Understanding the interaction between mandatory and voluntary disclosure will provide the regulators with useful insights about the disclosure pattern in the market. For example, the positive relationship between mandatory and voluntary disclosure could be a sign that the increase in the level of mandatory disclosure encourages an increase in voluntary disclosure. However, some interviewees did not support this view, since the likelihood of providing voluntary disclosure is independent of mandatory disclosure. Thus, it could be said that there is still no clear pattern of relationship between mandatory and voluntary disclosures. Moreover, users of the annual reports (e.g. investors) should be advised not to suppose that there is a positive relationship between the level of mandatory disclosure and voluntary disclosure. In other words, companies that are better in disclosing mandatory items are not always the companies that disclose more voluntary information.

\section{Limitations and Future Research}

The study has a number of limitations. First, the focus of this study was on one source of information, which is the annual reports. There are other sources of information in Jordan that could be useful for decision making, such as interim reports, AFM publications, prospectuses and financial press releases. Future research might be extended to investigate the disclosure practices for other forms of information. Moreover, the recent developments in technology and communications suggest a need to pay more attention to internet sources of information. Therefore, it would be interesting to investigate the level of internet disclosure after the new developments of technology, communications and regulations. Moreover, future research could identify the firm specific characteristics which influence the online disclosure practices for Jordanian companies.

Second, construction of the disclosure index and assigning scores implies subjective judgement. The disclosure index in this study is a proxy for measuring the extent of disclosure by the company. Bias exists here, since the 
researcher relied on contents of the annual reports, which may not always contain accurate information about the company. An avenue for future research is to employ a weighted disclosure index. The weighted index assesses the importance of each item in accordance with specific users' perspective (e.g. investors, financial analysts).

Third, there are some limitations as regards the interview data and analysis such as:

A- Translating the Arabic text into English text may not give a fully accurate transcript because some Arabic verbal utterances (especially non formal) have no English equivalent. However, the researcher reduced the subjectivity by matching the appropriate meaning for these Arabic verbal utterances to English, which would not affect the general meaning of the words or the sentence.

B- The study focused on interviewing specific user groups, regulators, auditors and a financial analyst, since they are the most relevant groups. Including more user groups such as managers and investors would provide different perspectives about disclosure issues in Jordan.

C- The sample size in the interview analysis (five interviewees) was small because it was viewed as a Secondary source of data collection. In addition, these interviews required official permission. While average duration was $1 \frac{1}{2}$ hours, more time would have given the opportunity to discuss further issues about disclosure in Jordan.

An interesting future research implies an extension of the study to compare disclosure between Jordan and other developing countries in the region (i.e. Middle Eastern countries). Collecting data for more companies in different countries, especially those with different disclosure regulations, would enhance the validation of the results in this study and would determine the differences and similarities in policy makers' decisions.

Moreover, the interaction and relationship between mandatory and voluntary disclosure is still under discussion. While quantitative results indicate a positive association, some interview results did not support such a result. Therefore, this is a motivation for future research to extend and test this relationship in different periods and for a larger sample. Such study will have a significant implication for regulators, that the flow of information in the capital market should consider the interaction among all different channels of information (i.e. mandatory and voluntary disclosures). In addition, the policy makers will have adequate knowledge to design the disclosure regulations in light of their influence on the level of disclosure for other sources of information (i.e. voluntary disclosure). Exploring such an interaction will provide an implication for researchers that mandatory and voluntary disclosures are not separated elements and researchers should take into consideration the relationship between them. Furthermore, exploring the interaction between components of mandatory disclosure (e.g. IASs, JSC requirements) and the different kinds of voluntary disclosure (e.g. press releases, online information) is also left for future research.

\section{References}

Abayo, A. G. (1992). The accountability and corporate disclosure practices in Tanzania. PhD Thesis, University of Glasgow.

Abd-Elsalam, O. H. (1999). The introduction and application of international accounting standards to accounting disclosure regulations of a capital market in developing country: The case of Egypt. PhD Thesis, Herriot-Watt University.

Adina, P., \& Ion, P. (2008). Aspects regarding corporate mandatory and voluntary disclsoure. Economic Science Series, 17(3), 1408-1412.

Ahmed, K., \& Nicholls, D. (1994). The impact of non-financial company characteristics on mandatory disclosure compliance in developing countries: The case of Bangladesh. The International Journal of Accounting, 29, 62-77.

Akhtaruddin, M. (2005). Corporate mandatory disclosure practices in Bangladesh. The International Journal of Accounting, 40, 399-422. http://dx.doi.org/10.1016/j.intacc.2005.09.007

Al-Akra, M., \& Hutchinson, P. (2013). Family firm disclosure and accounting regulation reform in the Middle East: The case of Jordan. Research in Accounting Regulation, 25, 101-107. http://dx.doi.org/10.1016/j.racreg.2012.11.003

Al-Akra, M., Eddie, I. A., \& Ali, M. J. (2010). The Influence of the introduction of accounting disclosure regulation on mandatory disclosure compliance: Evidence from Jordan. The British Accounting Review, 42, 170-186. http://dx.doi.org/10.1016/j.bar.2010.04.001

Ali, M., Ahmed, M., \& Henry, D. (2004). Disclosure compliance with national accounting standards by listed companies in South Asia. Accounting and Business Research, 34(3), $183-199$. 
http://dx.doi.org/10.1080/00014788.2004.9729963

Al-Issa, Y. A. M. (1988). The usefulness of corporate financial disclosure to investors in the Amman financial market. PhD Thesis, University of Lancaster.

Al-Khasib, S. (2004). The economic annual report for the year 2003 in comparison to the 2002. Amman Chamber of Commerce, Students and Training Department, May.

Al-Mulhem, A. A. (1997). An empirical investigation of the level of financial disclosure by Saudi Arabia corporations. PhD Thesis, The University of Hull.

Al-Razeen, A., \& Karbhari, Y. (2004). Interaction between compulsory and voluntary disclosure in Saudi Arabian corporate annual reports. Managerial Auditing Journal, 19(3), 351-360. http://dx.doi.org/10.1108/02686900410524364

Al-Shiab, M. (2003). Financial consequences of IAS adoption: The case of Jordan. PhD Thesis, University of Newcastle Upon-Tyne.

Amman Financial Market Law No.1 for the year 1990, Amman, Jordan.

Amman Financial Market Law No.31 for the year 1976, Amman, Jordan.

Amman Stock Exchange. (2003). Fifth Annual Report, 2003, Amman, Jordan.

Amman Stock Exchange. (n. d.). Retrieved from http://www.ase.com.jo

Audit Law No.32 for the year 1985, Amman, Jordan.

Broberg, P., Tagesson, T., \& Collin, S. O. (2010). What explains variation in voluntary disclosure? A study of the annual reports of corporations listed on the Stockholm stock exchange. Journal of Management and Governance, 14, 351-377. http://dx.doi.org/10.1007/s10997-009-9104-y

Buzby, S. L. (1975). Company size, listed versus unlisted stocks, and the extent of financial disclosure. Journal of Accounting Research, 13(1), 16-37. http://dx.doi.org/10.2307/2490647

Chow, C. W., \& Wong-Boren, A. (1987). Voluntary financial disclosure by Mexican corporation. The Accounting Review, LXII(3), 533-541.

Collis, J., \& Hussey, R. (2003). Business research: A practical guide for undergraduate and postgraduate students (2nd ed.). Palgrave Macmillan, Basingstoke.

Companies Act No.1 for the year 1989, Amman, Jordan.

Cooke, T. E. (1989). An empirical study of financial disclosure by Swedish companies. New York: Garland Publishing, Inc.

Dye, R. A. (1985). Strategies accounting choice and the effect of alternative financial reporting requirements. Journal of Accounting Research, 23(2), 544-574. http://dx.doi.org/10.2307/2490826

Dye, R. A. (1986). Proprietary and nonproprietary disclosures. The Journal of Business, 59(2), 331-366. http://dx.doi.org/10.1086/296331

Einhorn, E. (2005). The nature of the interaction between mandatory and voluntary disclosures', Journal of Accounting Research, 43(4), September, 593-621. http://dx.doi.org/10.1111/j.1475-679X.2005.00183.x

El-Gazzar, S. M., \& Fornaro, J. M. (2012). Voluntary versus mandatory corporate disclosures on management responsibilities for financial reporting: An empirical investigation. Global Review of Accounting and Finance, $3(2), 74-93$.

Firth, M. (1979). The impact of size, stock market listing, and auditors on voluntary disclosure in corporate annual reports. Accounting and Business Research, 9(36), 273-280. http://dx.doi.org/10.1080/00014788.1979.9729168

Haniffa, R. M., \& Cooke, T. E. (2002). Culture, corporate governance and disclosure in Malaysian corporations. Abacus, 38(3), 317-349. http://dx.doi.org/10.1111/1467-6281.00112

Hossain, M. A., \& Taylor, P. J. (1998). Extent of disclosure in corporate annual reports in developing countries: A comparative study of India, Pakistan and Bangladesh. A Paper presented to the Cardiff Business School, School Conference in Financial Reporting (held on 6-7 July).

Hossain, M., \& Hammami, H. (2009). Voluntary disclosure in the annual reports of an emerging country: The case of Qatar. Advances in Accounting, incorporating Advances in International Accounting, 25(1), 255-265. 
Inchausti, B. G. (1997). The influence of company characteristics and accounting regulation on information disclosed by Spanish firms. The European Accounting Review, 6(1), 45-68. http://dx.doi.org/10.1080/096381897336863

Income Tax Law No.57 for the year 1985, Amman, Jordan.

Jordan Securities Commission. Retrieved from http://www.jsc.gov.jo

Khanna, T., Palepu, K. G., \& Srinivasan, S. (2004). Disclosure practices of foreign companies interacting with U.S. markets. Journal of Accounting Research, 42(2), 475-525. http://dx.doi.org/10.1111/j.1475-679X.2004.00146.x

Marston, C. L., \& Shrives, P. J. (1991). The use of disclosure indices in accounting research: A review article. British Accounting Review, 23, 195-210. http://dx.doi.org/10.1016/0890-8389(91)90080-L

Morse, J. M. (1991). Approaches to qualitative-quantitative methodological triangulation. Nursing Research, $40(1), 120-123$.

Naser, K., \& Nuseibeh, R. (2003). Quality of financial reporting: evidence from the listed saudi no financial companies. The International Journal of Accounting, 38, 41-69. http://dx.doi.org/10.1016/S0020-7063(03)00002-5

Neuman, W. L. (2006). Social research methods: Qualitative and quantitative approaches (6th ed.). Pearson International Edition, Boston.

Omar, B., \& Simon, J. (2011). Corporate aggregate disclosure practices in Jordan. Advances in Accounting, Incorporating Advances in International Accounting, 27, 166-186.

Owusu-Ansah, S., \& Yeoh, J. (2005). The effect of legislation on corporate disclosure practices. Abacus, 4l(1), 92-109. http://dx.doi.org/10.1111/j.1467-6281.2005.00171.x

Popova, T., Georgakopoulos, G., Sotiropoulos, I., \& Vasileiou, K. (2013). Mandatory disclosure and its impact on the company value. International Business Research, 6(5), 1-16.

Raffournier, B. (1995). The determinants of voluntary financial disclosure by Swiss listed companies. The European Accounting Review, 4(2), 261-280. http://dx.doi.org/10.1080/09638189500000016

Robertson, C. J., Al-Angari, H. A., \& Al-Alsheikh, S. A. (2012). The impact of voluntary disclosure on the mandatory disclosure of financial information: A study of companies on the Saudi Arabian stock exchange. International Journal of Management, 29(1), 379-388.

Securities Depository Centre. Retrieved from http://www.sdc.com.jo

Solas, C. (1994). Financial reporting practice in Jordan: An empirical test. Advances in International Accounting, 7, 43-60.

Suwaidan, M. S. (1997). Voluntary disclosure of accounting information: The case of Jordan. PhD Thesis, University of Aberdeen.

Tai, B. Y. K., Au-Yeung, P. K., Kwok, M. C. M., \& Lau, L. W. C. (1990). Non-compliance with disclosure requirements in financial statements: The case of Hong Kong companies. The International Journal of Accounting, 25, 99-112.

Taplin, R., Tower, G., \& Hancock, P. (2002). Disclosure (discernibility) and compliance of accounting policies: Asia- Pacific evidence. Accounting Forum, 26(2), 172-190. http://dx.doi.org/10.1111/1467-6303.00085

The Securities Law No. 23 of 1997, Amman, Jordan.

Tower, G., Hancock, P., \& Taplin, R. H. (1999). A regional study of listed companies' compliance with international accounting standards. Accounting Forum, 23(3), 293-305. http://dx.doi.org/10.1111/1467-6303.00016

Tsalavoutas, I. (2011). Transition to IFRS and compliance with mandatory disclosure requirement: What is the signal? Advances in Accounting, incorporating Advances in International Accounting, 27, 390-405.

Walker, R. G., \& Mack, J. (1998). The influence of regulation on the publication of consolidated statements. Abacus, 34(1), 48-74. http://dx.doi.org/10.1111/1467-6281.00022

Wallace, R. S. O. (1988). Corporate financial reporting in Nigeria. Accounting and Business Research, 18(72), 352-362. http://dx.doi.org/10.1080/00014788.1988.9729382 


\section{Notes}

Note 1. Source: Amman Stock Exchange: http://www.ase.com.jo

Note 2. Source: Amman Stock Exchange: http://www.ase.com.jo

Note 3. Source: Amman Chamber of Commerce, Studies and Training Development: The Economic Annual Report for the year 2003 in comparison to 2002, Al-Khasib, May, 2004.

Note 4. The Securities Law No.23 for the year 1997, Article 24.

Note 5. Many companies in Jordan do not keep their annual reports for long periods (such as 6 or seven years). Therefore, it was difficult to obtain the annual reports for the year 1996.

Note 6. The financial year for this company ended on 30/6 and hence the annual report for this company was not consistent with the annual reports for the other companies, whose financial year ended on 31/12.

Note 7. Securities Law No.23 for the year 1997, Article 6, Chapter Two.

Note 8. Securities Law No.23 for the year 1997, Article 24, Chapter Six.

\section{Copyrights}

Copyright for this article is retained by the author(s), with first publication rights granted to the journal.

This is an open-access article distributed under the terms and conditions of the Creative Commons Attribution license (http://creativecommons.org/licenses/by/3.0/). 